\title{
MODEL INTERAKSI DAN RESEPSI DOSEN PERGURUAN TINGGI ISLAM TERHADAP AL-QUR'AN
}

\author{
Naqiyah Naqiyah \\ Institut Agama Islam Negeri (IAIN) Purwokerto \\ naqiyah.mukhtar@iainpurwokerto.ac.id
}

\begin{abstract}
There are various kinds of interactions between people and the Qur'an in Muslim societies. Ideally, lecturers of Islamic universities have a quality interaction to the Qur'an. This paper aims at elaborating various models of interaction in behaving the Qur'an by the lecturers of IAIN Purwokerto. It explores the forms, values, motives and interpretations of lecturers' interaction to the Qur'an. The research employs an integrative approach by combining social approach of David Murley's reception theory on three possibilities for accepting text and religious approach on three levels of worshipers. The paper argues that the way the lecturers behave the Qur'an is classified into four receptive model of interaction: liturgical, aesthetic, intellectual, and mystical reception. The four model of interactions are mostly representing the 'dominant reading,' where they interact to the Qur'an as it was. While some others are typically representing the 'negotiated reading' and even 'transactional,' where they improve a new reading of the Qur'an which in line to their socio-cultural milieu.
\end{abstract}

Keywords: the Qur'an, lecturer, interaction, reception

\begin{abstract}
Abstrak: Ada berbagai macam interaksi antara manusia dan al-Qur'an dalam masyarakat Muslim. Idealnya dosen perguruan tinggi Islam dapat berinteraksi dengan al-Qur'an dengan tingkat kuantitas dan kualitas yang baik. Tulisan ini bertujuan untuk mengelaborasi berbagai model interaksi dosen IAIN Purwokerto terhadap al-Qur'an. Artikel ini menggali tentang bentuk, nilai, motif dan interpretasi dari interaksi dosen dengan al-Qur'an. Penelitian ini menggunakan pendekatan integratif dengan menggabungkan pendekatan sosial dari teori resepsi David Murley tentang tiga kemungkinan penerimaan teks, dan pendekatan agama tentang tiga tingkatan ibadah. Artikel ini berpendapat bahwa model interaksi dosen terhadap al-Qur'an dapat diklasifikasikan ke dalam empat bentuk: resepsi liturgis, estetis, intelektual, dan mistis. Keempat model interaksi tersebut sebagian besar merepresentasikan model 'dominant reading,' di mana mereka berinteraksi dengan al-Qur'an apa adanya. Sementara sebagian yang lain merepresentasikan model 'negotiated reading,' dan bahkan 'transaksional,' di mana mereka melakukan improvisasi dalam membaca al-Qur'an yang disesuaikan dengan lingkungan sosial budaya mereka.
\end{abstract}

Kata kunci: al-Qur'an, dosen, interaksi, resepsi. 


\section{Pendahuluan}

Kehidupan masyarakat Muslim tidak bisa dilepaskan dari sakralitas keberagamaan yang tersimpulkan dari interaksi mereka dengan al-Qur'an. Sebagai wasiat 'terakhir' dari Nabi Muhammad, alQur'an menempati posisi tertinggi dalam dimensi kehidupan masyarakat Muslim. Pasalnya, Nabi berpesan kepada umatnya untuk berpegang teguh pada tali agama, yang tidak lain adalah al-Qur'an dan hadis. Jika hadis telah banyak tercemari oleh isu fabrikasi, maka otentisitas al-Qur'an masih tetap diyakini para pemeluknya. Setidaknya dengan kerangka jalur periwayatan yang bersifat 'mutawatir', al-Qur'an menjadi satu-satunya dokumen sejarah yang paling sakral dalam kehidupan umat Islam.

Interaksi masyarakat Muslim dengan sakralitas al-Qur'an memiliki ragam bentuk, intensi dan resepsi yang berbeda-beda. ${ }^{1}$ Masing-masing kelompok umat Islam, dari berbagai latar kebudayaan, tingkat sosial dan kematangan intelektual, memiliki caranya masing-masing dalam memperlakukan al-Qur'an sebagai teks yang sakral. Sakralitas ini, setidaknya, bisa disimpulkan dari persepsi universal masyarakat Muslim bahwa al-Qur'an merupakan kalam Allah yang bisa memberi inspirasi dan petunjuk bagi umatnya. Al-Qur'an sendiri telah mentahbiskan dirinya sebagai teks yang bersifat ' $b u d \bar{a}$, yang berarti petunjuk untuk umat manusia. Meski dalam level tertentu, makna petunjuk ini dipahami dalam dimensi makna yang beragam.

Beberapa tulisan yang membahas tentang resepsi masyarakat Muslim terhadap al-Qur'an yang hidup di masyarakat muslim dapat diklasifikasikan pada beberapa bentuk yakni: liturgis dengan membaca ayat-ayat dan atau surah-surah tertentu, menghafal al-Qur'an, estetis baik dengan lisan berupa mujawwad untuk acara seremonial maupun dengan tulisan berupa kaligrafi, dan dalam bentuk magis. Beberapa tulisan tersebut di antaranya adalah Isnawati menyimpulkan bahwa Ibu hamil membaca surah dan ayat al-Qur'an secara kontinyu dengan tujuan memperoleh berkah baik untuk dirinya maupun anak yang akan dilahirkannya. ${ }^{2}$ Muhtador menyatakan bahwa mujahadah dengan media potongan ayat al-Qur'an dapat memberikan ketenangan di

1 Sahiron Syamsuddin, "Metodologi Peneltian Living Qur'an Dan Hadis," in Metodologi Penelitian Living Qur'an Dan Hadis, ed. Sahiron Syamsuddin (Yogyakarta: Teras, 2007).

2 Isnawati, "Studi Living Qur'an Terhadap Amalan Ibu Hamil," Studia Insania, Vol. 3, No. 2 (2015), 125-138. 
samping mengabulkan apa yang diinginkan, walaupun perlu disertai dengan placebo effect dengan mengaktifkan keyakinan pelakunya. ${ }^{3}$ Atabik yang menyimpulkan bahwa tahfidh merupakan upaya komunitas muslim untuk menghadirkan al-Qur'an dalam kehidupannya. $^{4}$

Demikian juga kesimpulan yang dilakukan oleh Suyatno Prodjodikoro bahwa aktivitas semaan dimaknai untuk mendapat kesenangan batin dan lahir. ${ }^{5}$ Uswatun Hasanah menemukan dalam penelitiannya bahwa tujuan masyarakat membaca Al-Qura'an untuk menentramkan jiwa, mendapatkan pahala, mengusir setan, dan obat penyakit jasmani. Kemudian, Imam Sudarmoko dalam karya tesisnya menyimpulkan semaan al-Qur'an Sabtu Legi di Sooko Ponorogo bermotifkan agama dan non-agama berupa memelihara dan melestarikan hafalan, belajar, mendapat hidayah, syafaat, dan berkah, dan obat psikis dan fisik. Selanjtnya, Imam Sudarmoko menyampaikan kegiatan semaan dimaknai sebagai hiburan religius, sarana dakwah, sarana ukhuwah, penolak balak, dan sarana mendekatkan diri kepada Allah, dan pendidikan spiritual. ${ }^{6}$ Heddy Shri Ashima Putra membahas tentang makna al-Qur'an dengan pendekatan antropologis dapat menggunakan beberapa perspektif seperti akulturasi, difusi, fungsional struktural, fenominologi, dan hermeneutik atau interpretif. ${ }^{7}$ Ia menemukan bahwa masyarakat memaknani al-Qur'an secara beraneka ragam yaitu bahwa ia sebagai kitab suci harus dibaca, dihafalkan, dihias, dikeramatkan. Juga, alQur'an sebagai yang perlu dikaji, sebagai obat psikis dan fisik, sarana peelindungan dari beragam bahaya (alam, makhluk halus, siksa kubur,

3 Moh. Muhtador, "Pemaknaan Ayat Al-Quran Dalam Mujahadah: Studi Living Qur'an Di PP Al-Munawwir Krapyak Komplek Al- Kandiyas Moh.” Jurnal Penelitian, Vol. 8, No. 1 (2014), 93-112.

4 Ahmad Atabik, "The Living Qur'an: Potret Budaya Tahfiz al-Qur'an Di Nusantara," Jurnal Penelitian, Vol. 8, No. 1 (2014): 161-178.

5 Sumatno Prodjodikoro, "Dimensi Spiritual Dan Sosial Semaan Al-Qur'an 'MANTAP' Di Yogyakarta," Aljamiah 39 (2001): 174-193. Lihat juga, Ainun Hakiemah dan Jazilus Sakhok, "Khataman al-Qur'an di Pesantren Sunan Pandanaran Yogyakarta: Kajian Living Hadis," Mutawatir: Jurnal Keilmuan Tafsir Hadith, Vol. 9, No. 1 (2019).

${ }^{6}$ Imam Sudarmoko, “The Living Qur'an; Studi Kasus Tradisi Sema'an Al-Qur'an Sabtu Legi Di Masyarakat Sooko Ponorogo" (Universitas Islam Negeri Maulana Malik Ibrahim Malang, 2016).

7 Heddy Shri Ahimsa-Putra, "The Living Al-Qur'an: Beberapa Perspektif Antropologi,” Walisongo: Jurnal Penelitian Sosial Keagamaan, Vol. 20, No. 1 (2012), 235. 
dan kemiskinan), di samping sumber (mencari rizki dan pengetahuan). ${ }^{8}$

Dalam kerangka untuk memotret interaksi antara kedua entitas, yaitu al-Qur'an dan masyarakat Muslim, artikel ini hendak menyajikan satu fragmen kehidupan masyarakat Muslim yang nampaknya masih jarang dikaji, yaitu dosen Perguruan Tinggi Agama Islam Negeri (PTAIN). Artikel ini menyasar objek tersebut dengan asumsi dasar bahwa dosen-dosen PTAIN tentunya adalah mereka yang memiliki kapasitas intelektual dan memiliki kelekatan tersendiri dengan alQur'an sebagai entitas terpenting dalam struktur kehidupan umat Islam. Dosen PTAIN umumnya termasuk kalangan intelektual yang dipersepsikan menguasai kandungan-kandungan makna al-Qur'an, selain itu mereka juga lekat dengan dinamika pemikiran-pemikiran keislaman yang lebih menitikberatkan pada aspek rasional. Oleh karenanya perpaduan antara rasionalitas seorang intelektual, emosionalitas seorang makhluk sosial, dan spiritualitas seorang yang beragama menjadi hal yang menarik untuk dipotret tentang bagaimana relasi ketiganya dalam berinteraksi dengan al-Qur'an.

Artikel ini hendak mendiskusikan bagaimana interaksi dosen dan al-Qur'an dengan mengambil sampel di Lembaga Pendidikan Tinggi, yaitu IAIN Purwokerto. Penulis berargumen bahwa meski dosen dipersepsikan sebagai individu yang memiliki kematangan intelektual, namun dalam realitasnya tidak semua dosen bisa membaca al-Qur'an dan memahami kandungan al-Qur'an secara rasional. Di sisi lain, penulis juga akan menunjukan bahwa model interaksi para dosen dengan al-Qur'an di IAIN purwokerto memiliki aneka ragam bentuk, mulai dari yang berbentuk liturgis, estetis, intelektual, dan bahkan sampai pada yang berbentuk magis. Meski mereka berada dalam milieu akademik, hal ini terjadi di antaranya karena mereka mempunyai background yang beragam, baik latar keluarga, pendidikan, maupun lingkungan masyarakat. Hal lain yang juga mendorong terciptanya model interaksi yang beragam ini adalah keterbukaan birokrasi dan masyarakat IAIN Purwokerto yang memberikan ruang dan bahkan mengapresiasi keberagaman tersebut sehingga semuanya bisa eksis dan bahkan berkembang dalam karakteristiknya masing-masing. Selain itu, budaya 'Banyumas' yang egaliter nampak ikut berkontribusi dalam pengembangan berbagai ketertarikan dan bakat yang dimiliki oleh para dosen IAIN Purwokerto dalam berinteraksi dengan al-Qur'an.

${ }^{8}$ Ibid. 
Secara khusus, artikel ini diarahkan untuk mengkaji studi alQur'an yang diresepsi oleh dosen IAIN Purwokerto, yang meliputi: bentuk interaksi dosen IAIN Purwokerto terhadap al-Qur'an, bagiamana pemaknaan mereka terhadap ragam bentuk interaksinya dengan al-Qur'an, dan sejauh mana mereka mengembangkan ragam interaksi tersebut di lingkungannya.

Tulisan dalam artikel ini berbasis pada penelitian kualitatif dengan model field research yang bersifat deskriptif analitis ${ }^{9}$ dan komparatifkonstruktif. Penelitian ini dilaksanakan di IAIN Purwokerto, dengan subyek dosen PNS, dengan latar belakang pendidikan yang beragam sehingga dapat mewakili dosen secara keseluruhan. Informan ditentukan secara purposive, yang disebut sebagai key informan. Teknik ini mencakup orang-orang yang diseleksi dengan menggunakan kriteria-kriteria tertentu yang dibuat peneliti berdasarkan tujuan penelitian. ${ }^{10}$ Selanjutnya key informant akan menunjuk informan lain secara snowball. Adapun jumlah informan tidak ditentukan secara limitatif. ${ }^{11}$ Objek yang diteliti berupa domain-domain yang terdiri atas: bentuk interaksi dosen IAIN Purwokerto terhadap al-Qur'an dan pemaknaan dosen IAIN Purwokerto terhadap ragam bentuk interaksi al-Qur'an tersebut.

\section{Resepsi Sosial dan Tipologi Ibadah}

Dalam diskursus akademik, beberapa studi tentang al-Qur'an kini menyasar ke ranah sosial. Kajian ini termasuk baru, karena umumnya studi tentang al-Qur'an berbasis pada teks. Kita mungkin bisa menemukan minimnya akademisi yang bergelut dengan kajian alQur'an mengkajinya dari fenomena sosial. Dalam konteks ini, kajian sosial atas al-Qur'an ini di Indonesia sering disebut dengan living Qur'an, umumnya juga disebut dengan lived Qur'an. Secara sederhana kajian tentang living Qur'an adalah kajian tentang al-Qur'an yang hidup dalam masyarakat. Kajian ini melihat bagaimana ragam model masyarakat Muslim dalam menghidupkan al-Qur'an dalam keseharian dan tradisi mereka.

Salah satu teori yang jamak dipakai dalam kajian living Qur'an adalah teori resepsi, yaitu tentang bagaimana masyarakat Muslim

${ }^{9}$ Saifuddin Anwar, Metode Penelitian (Yogyakarta: Pustaka Pelajar, 1998), 6.

${ }^{10}$ Kriyantono, Teknia Praktis Media Komunikasi (Jakarta: Kencana Prenada Media Grup, 2007), 154.

11 Moleong J Lexy, Metodologi Penelitian Qualitatif (Bandung: PT Remaja Rosdakarya, 1996). 
menerima dan memberikan respon terhadap al-Qur'an sebagai teks, yang merupakan interaksi antara pendengar dan teks bacaan. Dengan analisis resepsi akan diketahui penerimaan khalayak, yang menurut David Murley ada tiga kemungkinan dalam menerima teks: dominant (hegemonic) reading, negotiated reading, dan oppositional (encounter 'begemonic') reading. ${ }^{12}$ Dalam dominant reading, seorang pembaca hanya akan menerima teks apa adanya, tanpa ada negosiasi ataupun resistensi makna yang dibacanya. Sedangkan negotiated reading lebih mengarah pada sebuah pembacaan di mana seseorang melakukan negosiasi makna teks yang dibacanya. Dari pembacaan ini, ada kemungkinan lahirnya makna baru yang dihadirkan oleh pembaca melalui proses negosiasi tersebut. Artinya, seorang pembaca tidak hanya menerima teks apa adanya, namun lebih terlebih dahulu dihadapkan dengan prior text atau persepsi-persepsi yang dimiliki oleh pembaca. Adapun oppositional reading memiliki tingkat yang sama dengan memperlakukan teks, hanya saja, seorang pembaca lebih bersifat resisten terhadap teks yang dibacanya. Teori resepsi inilah yang akan digunakan untuk melihat bagaimana dosen IAIN Purwokerto memaknai ragam interaksi mereka terhadap al-Qur'an.

Dalam hal ini ada beberapa kemungkinan analisis, pertama, diterima secara keseluruhan sebagai dominant reading sebagaimana yang diidealkan dalam teks al-Qur'an atau pemahaman para mufasir terhadap teks tersebut. Kedua, diterima secara negosiatif, yakni sesuai dengan pengalaman individu-individu penerimanya yang dikategorikan pada negotiated reading. Dan ketiga, adanya kemungkinan untuk ditolak sehingga memaknai teks dengan pemahamannya sendiri yang sama sekali dapat berbeda atau bahkan bertentangan dengan yang "dikehendaki" teks atau penafsirnya, yang disebut dengan oppositional reading. Sehingga, analisis resepsi memfokuskan pada proses pemaknaan dan pemahaman mendalam terhadap teks, yang pada dasarnya bersifat polisemi, bagaimana penerima menginterpretasikan teks tersebut, mengapa mereka menginterpretasikan teks yang sama secara beragam, dan bagaimana mereka memaknai teks dan pengaruhnya dalam kehidupan keseharian mereka.

Selain teori resepsi, tulisan ini juga menggunakan kerangka tipologi beribadah menurut al-Ghazāili. Tipologi ini digunakan untuk

12 David Murley, Family Televition, Cultural Power and Domintic Leisure, (London: A Comedia Book, 1986). Lihat juga, Tri Nogroho Adi, "Mengkaji Khalayak Media Dengan Metode Resepsi," Acta Diurna, Vol. 8, No. 1 (2012), 27. 
memudahkan klasifikasi model dan motif para dosen dalam melakukan interaksi dengan al-Qur'an. Dalam pandangan al-Ghazāil, terdapat tiga level orang yang beribadah: ibadah orang awam, ibadah orang khusus, dan ibadah orang yang sangat khusus (istimewa). Dalam paparannya, al-Ghazāli memberikan gambaran tentang tiga tingkatan bagi orang yang berpuasa, yaitu: 1) Puasa orang awam, yang hanya dilakukan untuk menahan dari lapar dan hubungan seksual, atau dari hal-hal yang bisa membatalkan puasa; 2) Puasa orang khusus, yaitu puasa orang yang di samping menahan lapar dan seks, orang tersebut juga menjaga pendengaran, penglihatan, lisan, tangan, kaki, dan anggota tubuh lainnya dari hal-hal yang menyebabkan dosa. Pada tingkat ini, seseorang memiliki tingkat spiritualitas yang lebih tinggi dibanding tingkatan awam; 3) Puasa orang yang yang istimewa, yakni selain dengan kedua tingkatan sebelumnya, orang tersebut berpuasa dengan menjaga dan melatih hati dari nafsu dan pikiran duniawi, dan mencurahkan segala dayanya untuk meningkatkan spiritualitasnya dalam berinteraksi dengan Allah. ${ }^{13}$

Dari uraian di atas, penulis mengkategorisasikan ragam tipologi orang beribadah sebagai berikut: 'budak' yang beribadah karena rasa takut, 'pebisnis' yang beribadah karena mengharapkan untung (pahala), 'arif yang beribadah karena rasa syukur terhadap anugerah yang telah diterimanya. Tiga tipologi ini akan digunakan untuk menganalisis interaksi dosen IAIN Purwokerto terhadap al-Qur'an yang berupa bentuk, penilaian, dan pengembangan dalam lingkungannya.

\section{Resepsi Dosen atas al-Qur'an}

Dalam diskursus living Qur'an, bentuk-bentuk resepsi masyarakat Muslim dengan al-Qur'an umumnya dikategorisasikan ke dalam empat model, yaitu: liturgis, estetis, intelektual, dan magis. Interaksi liturgis umumnya melihat proses interaksi masyarakat Muslim dengan alQur'an dalam kerangka peribadatan. Dalam konteks ini, al-Qur'an dijadikan sebagai teks sakral yang dipersepsikan bisa mendatangkan keberkahan atau pahala ketika dibaca. Oleh karenanya proses interaksi liturgis umumnya melihat bagaimana masyarakat membaca al-Qur'an sesuai dengan kaidah-kaidah bacaan (tajwid) baik itu melalui proses

13 Muhammad Jamāl al-Dīn b. Muhammad Sāīd b. Qāsim al-Ḥallaq al-Qāsimī, Maw'izat al-Mu'minīn min Ibya ', 'Ulüm al-Dīn (Beirut: Dār al-Kutb al-'Ilmiyah, t.th.), 61. 
talaqqi $\bar{i}$, tartil al-Qur'an, membaca surah-surah dan atau ayat-ayat tertentu, membaca ayat-ayat al-Qur'an yang dipadukan dengan kalimat-kalimat tayyibah, dan menghafal al-Qur'an. Adapun bentuk interaksi estetis lebih banyak digunakan untuk melihat model-model pembacaan al-Qur'an yang dipadukan dengan kesenian, seperti ilmu nagham baik dengan murattal ${ }^{14}$ maupun mujawwad. ${ }^{15}$ Di samping itu, interaksi estetis tidak hanya menyasar aspek kesenian dalam pelafalan, namun juga penulisan al-Qur'an. Dalam konteks ini, penulisan alQur'an dengan menggunakan khatt (tulisan indah) tertentu, umumnya disebut dengan kaligrafi al-Qur'an, menjadi satu format interaksi masyarakat Muslim untuk menikmati keindahannya dari aspek tulisan. Kemudian, interaksi yang berbentuk intelektual umumnya termanifestasikan ke dalam karya-karya yang berupa terjemah alQur'an, kajian di bidang tafsir, dan kajian 'ulum al-Qur'an. Dan terakhir, interaksi magis umumnya masyarakat Muslim menggunakan teks al-Qur'an sebagai media untuk pengobatan atau praktik-praktik magis lainnya.

Adapun di kalangan dosen IAIN Purwokerto, penulis menemukan beberapa bentuk interaksi dan resepsi mereka dengan alQur'an dalam beberapa bentuk, yaitu:

\section{Resepsi Liturgis}

\section{a. Belajar Membaca al-Qur'an}

Di antara bentuk resepsi al-Qur'an adalah liturgis yang berupa belajar membaca al-Qur'an. Walaupun IAIN Purwokerto merupakan institusi perguruan tinggi agama Islam, nampaknya masih ada beberapa dosen yang belum bisa membaca al-Qur'an dengan benar sesuai dengan kaidah-kidah ilmu tajwid. Hal ini penulis buktikan bahwa terdapat beberapa dosen IAIN Purwokerto yang tidak lulus dalam tes baca tulis al-Qur'an (BTA) yang telah diwajibkan di IAIN Purwokerto. Dalma konteks inilah kemudian mereka berusaha mendekati al-Qur'an secara liturgis, yaitu dengan belajar membaca alQur'an dengan muatan-muatan keilmuan tajwid, seperti makhraj, sifat huruf, dan ilmu-ilmu car abaca al-Qur'an lainnya.

14 Murattal membaca al-Qur'an dengan menekankan pada penerapan ilmu tajwid yang dilengkapi dengan irama lagu.

${ }^{15}$ Mujawwad adalah teknik membaca Al-Qur'an di samping dengan ilmu tajwid juga menggunakan irama lagu secara sempurna, baik dalam tingkatan nada maupun jenis dan variasi lagunya. 
Fenomena ini nampaknya cukup menarik untuk diperhatikan. Pertanyaan yang muncul kemudian adalah mengapa mereka sebagai orang Islam tidak bisa membaca al-Qur'an yang notabenenya adalah kitab suci yang menjadi sumber dan pedoman kehidupan beragama mereka? Lalu, bagaimana mereka bisa menjadi dosen di IAIN Purwokerto, yang notabenenya adalah perguruan tinggi Islam yang menempatkan al-Qur'an sebagai sumber utama dalam konstruksi pengetahuan institusional? Dan mengapa mereka harus bisa membaca al-Qur'an? Untuk menjawab pertanyaan-pertanyaan tersebut perlu melihat background masing-masing dosen. Nampaknya, dosen-dosen yang tidak memiliki kapabilitas untuk membaca al-Qur'an dengan baik pada umumnya memiliki latarbelakang pendidikan perguruan tinggi umum (PTU). Selain itu, mereka juga hidup dalam lingkungan keluarga yang kurang memperhatikan dan tidak cukup memiliki anggapan akan pentingnya belajar membaca al-Qur'an. Oleh karenanya, rata-rata para dosen tersebut tidak memiliki latar belakang pendidikan keislaman, seperti pesantren.

Di Indonesia, tidak semua orang Islam bisa membaca al-Qur'an dengan benar, karena sangat tergantung pada lingkungannya baik dalam keluarga, sekolah, maupun masyarakatnya. Hal ini merupakan dampak dari sistem pendidikan yang menerapkan dikotomi antara ilmu agama dan ilmu pengetahuan umum. Kemudian, untuk menjawab pertanyaan kedua, mereka bisa diterima untuk menjadi dosen IAIN, karena sistem rekrutmen dosen ditekankan pada keahlian bidang keilmuan tertentu. Jika yang diperlukan pengampu matakuliah umum, maka yang direkrut adalah orang yang memiliki latar belakang sesuai bidang tersebut, tanpa ada keharusan untuk memiliki pengetahuan agama, termasuk membaca al-Qur'an. Hal ini nampaknya merupakan efek modernisasi institusional yang menghendaki keterbukaan dalam membuka program-program studi baru yang bersifat keilmuan terapan (applied science). Keterbukaan (openness) inilah yang telah menjadi weltenschaung bagi perguruanperguruan tinggi keislaman di Indonesia sejak awal tahun 2000-an yang paradigma integrasi keilmuan, yaitu antara ilmu keagamaan yang menjadi basis core perguruan tinggi keislaman dengan ilmu-ilmu umum, sains atau ilmu-ilmu terapan. Secara institusional, perguruan tinggi yang mengaplikasikan model terintegrasi ini memiliki kehendak untuk merubah institusinya menjadi universitas yang secara juridis bisa menampung berbagai macam disiplin keilmuan. 
Lalu, bagaimana dengan pertanyaan terakhir? Walaupun mereka mengampu matakuliah umum, nampaknya secara institusional mereka tetap diwajibkan untuk bisa membaca al-Qur'an. Hal itu seperti dikemukakan sebelum, yaitu karena tuntutan paradigma integrasi keilmuan antara ilmu agama dan ilmu umum di lingkungan IAIN Purwokerto. Di samping itu, ada juga faktor eksternal lain yang nampaknya turut mendukung terciptanya model resepsi liturgis para dosen terhadap al-Qur'an ini, yaitu adanya tuntutan dari masyarakat umum terhadap dosen IAIN Purwokerto untuk bisa membina keagamaan di lingkungan masyarakatnya. Hal inilah yang kemudian menjadikan resepsi liturgis terhadap al-Qur'an menjadi domain utama dalam interaksi dosen terhadap al-Qur'an di lingkungan IAIN Purwokerto.

Lalu, bagaimana mereka memaknai belajar membaca al-Qur'an tersebut? Dalam hal ini mereka memaknainya secara beragam. Sebagian dari mereka berupaya untuk belajar membaca al-Qur'an, tidak dalam kerangka untuk memenuhi tuntutan dari lembaga tempat mereka bekerja, namun mereka juga merasa adanya kebutuhan yang mendesak dalam keberagamaan mereka untuk bisa membaca kitab suci agama yang dipeluknya sekaligus sebagai bekal untuk kehidupan kesehariannya. Selain itu, proses liturgi ini juga dipengaruhi oleh keinginan para dosen untuk bisa mengajari anak-anaknya dalam membaca al-Qur'an. Dalam konteks ini, di antara mereka ada yang mengatakan bahwa dirinya terinspirasi oleh sebuah hadis yang menyatakan bahwa "sebaik-baik kamu adalah orang yang belajar alQur'an dan mengajarkannya. ${ }^{16}$ Selain itu, ada juga tuntutan moral etis terhadap mereka ketika diminta untuk mengisi ceramah-ceramah di lingkungan masyarakat sekitarnya. Sebagian yang lain mungkin belajar lebih karena tuntutan lembaga, hal ini tampak pada mereka yang tidak menyambut dengan serius terhadap kewajiban untuk bisa membaca al-Qur'an sehingga tidak segera untuk mengikuti tes membaca alQur'an kembali.

Bagaimana bila bentuk liturgis sebagaimana diuaraikan di atas dinalisis dengan pendekatan resepsi? Sebagaimana dinyatakan pada bagian sebelumnya bahwa menurut David Murley ada tiga kemungkinan dalam menerima teks: dominant ('hegemonic') reading,

\footnotetext{
16 Muhammad b. Ismāīil al-Bukhāri, Al-jami al-Saḩịh al-Bukhāri, vol. 4 (Beirut: Dār Tawq al-Najāt, 1422 H), 192.
} 
negotiated reading, dan oppositional (encounter 'begemonic') reading. ${ }^{17}$ Secara ideal orang Islam, seharusnya bisa membaca al-Qur'an, lebih-lebih jika ia sebagai dosen perguruan tinggi keislaman dan ada kewajiban yang harus dipenuhi sebagai tenaga pendidik di perguruan tersebut. Namun dalam realitasnya, tidak semua dosen IAIN Purwokerto bisa membaca al-Qur'an sebagaimana telah dipaparkan di atas. Melihat kenyataan di atas, kita bisa melihat bahwa sebagian mereka mau belajar dan menerima tuntutan dari lembaga tersebut dengan serius, sementara sebagian lainnya tampak menerimanya dengan 'terpaksa.' Kondisi di atas jika dilihat dari pendekatan resepsi, yang pertama dapat dikategorikan pada dominant (begemonic) reading, mereka bisa menerima teks atau perintah tersebut apa adanya tanpa ada negosiasi ataupun resistensi terhadap teks tersebut. Sementara sebagian yang lainnya lebih cenderung untuk melakukan negotiated reading, karena keterpaksaannya tidak bisa melepaskan dirinya dari teks tersebut.

Jika bentuk liturgis tersebut ditelaah dengan pendekatan sufistik tipologi orang beribadah, maka terdapat tiga tipologi orang yang telah dipaparkan sebelumnya, yaitu: budak, pebisnis, dan 'árif. Berdasarkan data sebagaimana telah disampaikan pada bagian sebelumnya ditemukan bahwa dosen belajar membaca al-Qur'an dengan motivasi yang beragam. Sebagian mereka belajar al-Qur'an untuk memenuhi tuntutan institusi IAIN Purwokerto sehingga dapat dikategorikan pada tipologi buruh. Akan tetapi, pada umumnya mereka belajar membaca al-Qur'an karena kebutuhan: agar bisa membaca al-Qur'an untuk keperluan sendiri, untuk mengajari anak-anaknya, untuk memenuhi kewajiban yang telah dibebankan oleh institusi, untuk memenuhi tuntutan masyarakat, di samping untuk meraih kesempatan sertifikasi dosen sehingga dapat dikategorikan pada tipologi pebisnis.

Meski demikian, sebagian besar dari kalangan dosen meyakini bahwa membaca al-Qur'an merupakan bagian dari ibadah. Mereka mengetahui dengan baik akan adanya hadis yang menyatakan bahwa membaca al-Qur'an akan mendatangkan pahala sepuluh kali untuk setiap huruf yang dibaca. Hadis tersebut berbunyi:

"Barangsiapa membaca satu huruf dari Kitabullah (al-Qur'an), maka baginya satu pahala kebaikan dan satu pahala kebaikan akan dilipatgandakan menjadi sepuluh kali, aku tak mengatakan alif

${ }^{17}$ Murley, Family Televition, 71; Adi, "Mengkaji Khalayak Media," 27. 
laam miim itu satu huruf, akan tetapi alif satu huruf, laam satu huruf dan mim satu huruf'. ${ }^{18}$

\section{b. Membaca al-Qur'an}

Adapun dalam membaca al-Qur'an, terdapat tiga yang dapat dikategorisasikan dari model membaca al-Qur'an para dosen IAIN Purwokerto, yaitu: membaca al-Qur'an sesuai dengan tertib mushaf Uthmani, membaca surah-surah dan/atau ayat-ayat tertentu, dan membaca ayat-ayat khusus yang dipadukan dengan kalimat-kalimat tayyibah.

1) Membaca al-Qur'an sesuai urutan mushaf uthmani

Untuk model ini, dosen IAIN Purwokerto melakukannya secara beragam. Ada yang membaca dengan target tertentu seperti tiap hari empat hingga lima juz, sehingga mereka bisa menyelsaikan seluruh ayat al-Qur'an dalam sepekan. ${ }^{19}$ Ada yang membacanya tiga juz setiap hari, sehingga mereka selesai membaca al-Qur'an secara keseluruhan sebanyak tiga kali dalam satu bulan, dan hal itu telah dilakukan selama sebelas tahun. ${ }^{20}$ Selain itu, ada pula yang membaca satu juz setiap hari, sehingga dia bisa mengkhatamkan al-Qur'an sekali dalam sebulan. ${ }^{21}$ Ada juga yang membaca empat halaman sehari, ${ }^{22}$ ada yang lima halaman maksimal dan satu ruku' minimal, ${ }^{23}$ ada juga yang hanya membaca beberapa ayat, dan bahkan ada yang membaca hanya tiga ayat dalam sehari, ${ }^{24}$ dan ada pula yang mengkhatamkan al-Qur'an sekali dalam setahun. ${ }^{25}$ Di samping itu, ada yang membacanya tanpa target tertentu, melainkan lebih menekankan pada waktu, seperti setelah salat magrib dan subuh dan pada waktu malam hari. ${ }^{26}$ Terakhir, ada pula yang membaca al-Qur'an yang tanpa terstruktur. Mereka tidak memiliki model ataupun terget tertentu untuk membaca

\footnotetext{
${ }^{18}$ Abū 'Tsā Muhammad b. 'Tsāal-Turmudhi, Sunan al-Turmudhì (Beirut: Dār al-Gharb al-Islämi, 1988).

19 "Wawancara Dengan NM 15 Mei" (Purwokerto, 2017).

20 "Wawancara Dengan Spn 20 Mei" (Purwokerto, 2017).

21 "Wawancara Dengan SB 7 Juni" (Purwokerto, 2017).

22 "Wawancara Dengan HM 7 Juni" (Purwokerto, 2017).

23 "Wawancara Dengan WT 2 Mei" (Purwokerto, 2017).

24 "Wawancara Dengan HK 13 Juni" (Purwokerto, 2017).

25 "Wawancara Dengan YP 23 Mei" (Purwokerto, 2017).

26 "Wawancara Dengan EW and BU 25 Juli" (Purwokerto, 2017).
} 
al-Qur'an dan tidak pula menghususkan untuk membaca al-Qur'an pada waktu-waktu tertentu. ${ }^{27}$

Kemudian, pertanyaan berikutnya adalah tentang bagaimana para dosen tersebut memaknai interaksinya dengan al-Qur'an? Ada beberapa alasan yang dipaparkan oleh para dosen responded, yang dapat dirangkum sebagai berikut: al-Qur'an sebagai pedoman hidup, perlu diamalkan (dibaca) oleh penganutnya, dengan membacanya hidup menjadi teratur, dengan membaca secara istiqamah mendapatkan ketenangan hidup, ${ }^{28}$ doa dikabulkan dan bahkan lebih dari yang dibutuhkan sehingga benar-benar di luar nalar, ${ }^{29}$ dapat menemukan ide baru, dapat menambah kosa kata bahasa Arab, memahami maksud lain dari ayat al-Qur'an, ${ }^{30}$ sebagai medium untuk bertakarub kepada Allah, mengetahui keindahan al-Qur'an melalui struktur bahasa Arab al-Qur'an, sebagai medium peribadatan, memberi dampak positif pada orang lain, dan untuk mengingat Allah. ${ }^{31}$ Selain itu, ada pula yang memaknai interaksi tersebut dengan sebauah pandangan bahwa al-Qur'an merupakan menu utama atau makanan pokok umat Islam, sehingga perlu untuk diekstraksi agar bisa dikonsumsi baik secara lahir maupun batin. Dengan kerangka intelektual ini responden tersebut mengaku perlunya usaha untuk berfikir keras dalam menemukan sesuatu yang baru dari makna-makna al-Qur'an. ${ }^{32}$ Selain itu, ada pula yang memaknai bahwa semua yang lahir pada manusia harus merujuk pada al-Qur'an. Ada juga yang memaknai adanya fadillah, kandungannya luar biasa, dan dapat mendatangkan optimism ketika membaca al-Qur'an. Selain itu, yang lebih umum diutarakan oleh para responden adalah bahwa al-Qur'an sebagai kitab suci wajib dipelajari atau dibaca, minimal untuk memperoleh pahala dari bacaan tersebut. ${ }^{33}$

Interaksi dosen dengan al-Qur'an dalam bentuk membaca ayatayatnya sesuai dengan tertib mushaf Uthmani dengan pendekatan resepsi dapat dikategorikan pada tiga kemungkinan. Sebagiannya dapat dimasukkan pada dominant (begemonic) reading, hal ini tampak sebagian kalangan yang menerima dan meyakini bahwa membaca al-

\footnotetext{
27 "Wawancara Dengan YSS, CW, YE 5 Juni” (Purwokerto, 2017).

28 "Wawancara Dengan SM 23 Mei" (Purwokerto, 2017).

29 "Wawancara Dengan MR 15 Agustus" (Purwokerto, 2017).

30 "Wawancara Dengan EM 22 Mei" (Purwokerto, 2017).

31 "Wawancara Dengan SI 24 Mei" (Purwokerto, 2017).

32 "Wawancara Dengan Mw 25 Mei" (Purwokerto, 2017).

33 "Wawancara Dengan MH 24 Mei" (Purwokerto, 2017).
} 
Qur'an itu sebagai ibadah, sehingga berupaya untuk membacanya secara istikamah dengan target tertentu, walaupun tanpa memahaminya atau memahaminya secara tekstual. Sebagian lagi bisa digolongkan pada model negotieted reading, misalnya, ketika berupaya memahami al-Qur'an dan menerima pemahamannya secara tekstual ketika sesuai dengan pandangan dirinya, namun ketika tidak sesuai dengan pandangan dirinya, mereka mencari alternatif tafsiran lainnya sehingga dipahami bahwa ayat tersebut mempunyai multi tafsir. Kemudian, sebagian lainnya dapat dimasukkan pada oppositional (encounter hegemonic) reading, yakni berusaha menginterpretasikannya ayat yang sedang ditelaahnya dengan sedemikian rupa ketika pemahaman ayat tersebut secara tekstual tidak sesuai dengan pandangan dirinya

Selanjutnya, jika interaksi tersebut dianalisis dengan pendekatan tiga tiopologi orang beribadah (budak, pebisnis, dan 'árif) dapat dinyatakan bahwa secara umum dapat dikategorikan pada kalangan pebisnis. Hal ini dapat dilihat di antaranya pada penilaiannya bahwa dengan membaca al-Qur'an dapat hidup teratur, tenang, terkabul doanya, mendapatkan ide baru, memberi dampak positif pada orang lain, menambah ilmu, mendatangkan optimism, fadilab (keutamaan), dan memperoleh pahala. Selain itu, ada yang dikategorikan pada kalangan 'árif, seperti sebagian pandangan responden yang meyakini bahwa dengan membaca al-Qur'an merupakan medium mereka untuk mengingat dan mendekatkan diri kepada Allah.

2) Membaca surah-surah dan ayat-ayat tertentu

Membaca surah-surah atau ayat-ayat tertentu telah menjadi satu tradisi yang telah berjalan lama bagi para tenaga pendidik di IAIN Purwokerto pada umumnya. Adapun surah-surah yang dibaca adalah surah al-kahfi, al-sajdah, yāsin, al-dukhān, al-wāqia'ah, dan al-Mulk. Di samping itu adalah surah al-fatihah, ayat kursi, al-hasyr, al inshirāh, alfath, al-kāfirūn, mu'awwidhatayn, al-nās, dan surah-surah yang mengandung kisah. Kemudian, ayat-ayat tertentu yang dibaca adalah awal surah al-Baqarah, dan akhir surah al-Baqarah, dan ayat-ayat yang terdapat dalam tahlil.

Ketika dilakukan wawancara dengan para responden tentang surah yang dibaca pada umumnya mereka menyebut surah yāsin merupakan surah populer yang kerap dibaca oleh mereka. Hal tersebut dapat dipahamai karena surah tersebut telah melekat dalam tradisi, umumnya di kalangan Nahdlatul Ulama, untuk membaca surah 
yāsin, khususnya pada malam Jum'at yang diiringi dengan membaca tahlil. Selanjutnya yaitu surah al-wāqia'ah yang cukup populer dibaca oleh banyak dosen setiap hari, bahkan ada yang membacanya tujuh kali setiap hari. ${ }^{34}$ Lalu, ada surah al-fatihah dibaca selain dalam salat, ${ }^{35}$ dan ada pula yang membaca surah al-insyirāh sebanyak tiga kali setelah salat magrib dan isya dan beberapa ayat dari surah al-hasyr setelah salat magrib dan subuh. Bacaan yang terakhir ini dilakukan atas 'ijazah' atau pemberian amalan khusus dari gurunyanya yang meyakini akan anugerah dari merutinkan bacaan tersebut. Terlebih guru spiritualnya tersebut pernah mengatakan kepadanya bahwa "kamu cocok mengamalkan amalan ini," sehingga pelaku responden tersebut memiliki keyakinan unik bahwa bacaan-bacaan tersebut dapat memberi kesaktian yang berupa kekebalan tubuh dalam dirinya. ${ }^{36}$

Adapun motif dosen IAIN Purwokerto ketika membaca surahsurah tertentu dalam al-Qur'an, mereka memiliki alasan yang beragam. Di antara contohnya adalah karena kebiasaan, misalnya membaca surah yāin setiap malam Jum'at dalam tradisi tablilan di masyarakat. Kebiasaan itu terjadi karena adanya pandangan para pelaku yang meyakini adanya keutamaan dalam surah-surah tersebut ketika dibaca, khususnya mereka meyakini hal tersebut bisa menjadi doa bagi para leluhur yang telah mendahuluinya. Di samping itu, alasan lain yang bisa diutarakan adalah karena para pelaku mendapat amaliah khusus dari guru (kiai)-nya, sebagaimana yang dinyatakan oleh MR bahwa alasan kenapa membaca surah-surah tertentu adalah karena fadilahnya, meski alasan yang lebih mendasar adalah karena mendapat ijazah dari kiai, misalnya "Kalau mau masuk rumah, saya membaca surah al-ikhlaṣ, dapat ijazah dari kiai, agar rizkinya lancer." ${ }^{37}$ Hal yang sama juga yang disampaikan oleh Mt mengapa dia membaca surah al-

\footnotetext{
34 "Wawancara Dengan NF 24 Mei” (Purwokerto, 2017).

35 Ada yang membaca surah tersebut sebanyak seratus kali setiap hari dengan mekanisme sebagai berikut: setelah subuh tiga puluh kali, setelah duhur dua puluh lima kali, setelah asar dua puluh kali, setelah magrib lima belas kali, dan setalah isya sepuluh kali. Ada juga yang membaca surah al-fatihah secara rutin sebanyak serratus kali sehari sejak tahun 1984. Hal tersebut dilakuakan dalam kerangka penghormatan (ta'צim) terhadap guru tarekatnya, yaitu KH. Mohammad Dimyati, Banten. Di samping itu, surah tersebut diyakininya mengandung banyak fadilah sebagaimana yang terdapat dalam teks kitab Khazinat al-Asrär. "Wawancara Dengan MT 9 Agustus" (Purwokerto, 2017).

36 "Wawancara Dengan Htn 25 Mei" (Purwokerto, 2017).

37 "Wawancara Dengan MR 15 Agustus." (Purwokerto, 2017)
} 
fatiḥah seratus kali setiap hari. ${ }^{38}$ Alasan lainnya adalah karena kandungan isinya sebagaimana yang dinyatakan oleh Mtj, "bahwa saya membaca ayat kursi, al-nās, al-kāfirūn, al 'alaq, al-falaq, al-nās, dan beberapa surah tertentu karena saya tertarik pada kandungan maknanya." ${ }^{39}$

Demikian juga dengan membaca surah-surah atau ayat-ayat tertentu yang dipadukan dengan kalimat-kalimat tayyibah, seperti bacaan-bacan tahlil, wirid setelah salat, dan asmä al-husna (nama-nama baik Allah). Bagi para dosen IAIN Purwokerto, mereka memaknai pembacaan surah-surah atau ayat-ayat dan ayat-ayat yang dipadukan dengan kalimah tayyibah tersebut secara beragam. Di antaranya adalah karena sudah menjadi tradisi (kebiasaan), ijazah dari guru spiritual atau kiainya, fadilah yang terkandung di dalamnya, ${ }^{40}$ dapat membuat hati tenang, dapat menyehatkan, memberikan rasa optimis, ${ }^{41}$ sebagai obat terutama obat jiwa dan psikis, sarana untuk mendapatkan kemudahan dan bahkan dapat membuat orang yang mencuri bisa mengakui perbuatannya. ${ }^{42}$ Jadi, bacaan tersebut sebagai salah satu bentuk ikhtiar yang seringkali hasilnya di luar dugaan. ${ }^{43}$ Pemaknaan lainnya adalah karena al-Qur'an sebagai kitab suci wajib dipelajari (dibaca), dan membacanya minimal dapat mendatangkan pahala. ${ }^{44}$ Pemaknaan di atas jika dianalisis dengan menggunakan tiga tipologi kalangan orang yang beribadah secara umum dapat dikategorikan pada tipe pebisnis.

Membaca alasan yang disampaikan oleh dosen IAIN Purwokerto tentang interaksinya dengan al-Qur'an sebagaimana data yang telah dipaparkan sebelumnya, maka dengan pendekatan resepsi bisa dikategorikan pada beberapa model. Sebagian kalangan dalam mengamalkannya dapat dikategorikan pada dominant (begemonic) reading. Hal ini tampak dari sebagian kalangan yang membaca surah-surah atau ayat-ayat tertentu yang dipadukan dengan kalimat-kalimat tayyibah, karena mendapatkan ijazah dari guru spiritualnya, sehingga berupaya untuk membacanya secara istikamah. Mereka menerima amaliah tersebut apa adanya, tanpa mempertanyakan keabsahan, namun lebih jauh, mereka justru menyelami makna-makna dan ibrah

38 "Wawancara Dengan MT 9 Agustus." (purwokerto, 2017)

39 "Wawancara Dengan Mtj 12 Juni”" (Purwokerto, 2017).

40 "Wawancara Dengan MR 15 Agustus." (Purwokerto, 2017).

41 "Wawancara Dengan SS 27 Juni" (Purwokerto, 2017).

42 "Wawancara Dengan CS 29 Juni" (Purwokerto, 2017).

43 "Wawancara Dengan MR 15 Agustus." (Purwokerto, 2017).

44 "Wawancara Dengan WT 2 Mei." (Purwokerto, 2017). 
di balik amaliah tersebut. Bahkan, sebagian ada yang menyatakan sekalipun jelas surah atau ayat yang dibaca tersebut mempunyai fadilah khusus sebagimana yang disebutkan dalam hadis, tetapi yang bersangkutan mengaku membacanya secara istikamah lebih karena mendapatkan ijazah dari guru spiritualnya, dan hadis hanya sebagai pendukung. ${ }^{45}$ Model dominant reading ini nampaknya menjadi salah satu bentuk pembacaan yang cukup dominan di lingkungan pengajar IAIN Purwokerto. Adapun sebagian kebiasaan dosen yang lain lagi bisa digolongkan dalam kerangka negotiated reading, misalnya, ketika sebagian dosen membacanya dan kemudian menerimanya karena apa yang dibacanya tersebut sesuai dengan keyakinannya.

Jika data di atas dianalisis dengan tiga tipologi orang yang beribadah dapat dijelaskan sebagai berikut. Pada umumnya dapat dimasukkan pada tipologi pebisnis, misalnya karena keutamaannya dan supaya mudah kehidupan ekonominya. Di samping itu, ada juga yang dapat dikategorikan pada tipologi '́rif seperti yang membacanya karena tertarik pada isi dan kandungan teks al-Qur'an itu sendiri.

\section{c. Menghafal al-Qur'an}

Bentuk lain dari resepsi liturgis adalah menghafal al-Qur'an. Hal ini dilakukan oleh sebagian dosen IAIN Purwokerto. Untuk kategori hafalan al-Qur'an lengkap tiga puluh juz, hanya ada dua orang dosen yang telah menghafalkannya. Namun, untuk surah-surah pendek atau surah-surah favorit, banyak dari kalangan yang hafal. Bagi SM, misalnya, dengan menghafal al-Qur'an hidupnya menjadi lebih teratur, dan membacanya secara istikamah dapat menumbuhkan jiwa yang tenang serasa telah mencapai apa pun yang diinginkannya dengan sangat mudah. ${ }^{46}$

Bentuk resepsi liturgis berupa hafalan tersebut jika dibaca dengan pendekatan resepsi maka umumnya akan terlihat bahwa model dominant reading cukup dominan dalam latar penghafalan dan perapalan ayat-ayat suci al-Qur'an tersebut. Mereka tampak tidak ada yang menyangkal akan penghafalan teks-teks al-Qur'an tersebut. Terlebih mayoritas dari para dosen mengakui bahwa penjagaan al-Qur'an di antaranya adalah melalui hafalan dan lisan para hufaz. Namun tidak dipungkiri pula, bahwa model negotiated reading juga tampak dari

45 "Wawancara Dengan Rq 15 Agustus" (Purwokerto, 2017).

46 "Wawancara Dengan SM 23 Mei." (Purwokwrto 2017. 
perilaku mereka yang mencoba memaknai sendiri atas praktik-praktik pembacaan ayat-ayat al-Qur'an tersebut.

Selanjutnya jika pemaknaan tersebut dianslisis dengan menggunkan tiga tipologi orang yang beribadah dapat berada pada tipe pebisnis. Walaupun demikian perlu diurai lebih jauh, apakah alasan tersebut sebagai motivasi untuk menghafal al-Qur'an ataukah hanya sebagai dampak positif yang dirasakan setelah menghafal alQur'an. Kalau hanya sebagai dampak postif dan bukan sebagai motivasi, dapat dimasukkan pada the 'arif. Di samping itu, dapat juga dikategorikan pada 'abid, jika yang bersangkutan menghafalkan alQur'an karena patuh pada orang tua atau guru yang menyuruhnya.

\section{Resepsi Estetis}

Pada umumnya, para dosen IAIN Purwokerto memiliki perhatian terhadap aspek estetis dalam meresepsi al-Qur'an, baik berupa lisan, melalui bacaan-bacaan murattal maupun mujawwad. Mayoritas responden cukup aktif dalam membaca al-Qur'an secara murattal, namun hanya ada tiga orang saja dari para dosen di IAIN Purwokerto yang biasa aktif membacakan al-Qur'an secara mujawwad. Selain resepsi secara estetis secara oral, dosen IAIN Purwokerto juga berinteraksi dengan al-Qur'an secara estetis dalam bentuk tulisan, sekalipun pada umumnya mereka pasif, karena tidak memiliki keterampilan dalam menulis huruf-huruf Arab secara kaligrafis. Di antara para dosen, barangkali hanya EM yang aktif melakukan resepsi al-Qur'an melalui tulisan-tulisan indah dalam kaligrafi. ${ }^{47}$ Para dosen menyukai dalam bentuk estetis tersebut, baik yang dengan lisan maupun dengan tulisan karena resepsi estetis tersebut mampu memberikan kesan keindahan, kekaguman, kesesenangan, dan kenyamanan. Di antara contohnya adalah sebagaimana yang disampaikan oleh dosen berinisial Sfa bahwa "saya senang seperti asmā al husnā, al-rahmān, ayat kursī, al-insyirāḥ sehingga semua kamar di rumah saya ada kaligrafinya". ${ }^{48}$

Jika bentuk resepsi estetis berupa lisan dan tulisan sebagaimana telah didiskripsikan pada bagian sebelumnya dibaca dengan pendekatan resepsi, maka sebagian kalangan dalam mengamalkannya dapat dikategorikan pada dominant reading, hal ini tampak pada sebagian kalangan yang sengaja membaca al-Qur'an atau

47 "Wawancara Dengan EM 22 Mei." (purwokerto, 2017)

48 "Wawancara Dengan Sfa 15 August" (Purwokerto, 2017). 
mendengarkan bacaan al-Qur'an karena diajarkan oleh gurunya. Sebagian dosen yang lain tertarik lagi bisa digolongkan pada negotieted reading, misalnya, membaca atau menempel di rumahnya surah-surah atau ayat-ayat tertentu karena anjuran orang lain yakni gurunya di samping karena keindahannya. Demikian pula ketika sebagian dosen membaca atau menempel di rumahnya surah-surah atau ayat-ayat tertentu karena tertarik pada kandungannya dan atau pada keindahan bacaan atau tulisannya, hal ini tampak jelas masuk dalam kategori negotiated reading.

\section{Resepsi Intelektual}

Selanjutnya, bagaimana interaksi dosen IAIN Purwokerto dengan al-Qur'an dalam bentuk resepsi intelektual? Hal ini beragam bentuknya, mulai yang berupa pemahaman dan kajian ayat-ayat atau surah-surah al-Qur'an, baik melalui buku (terjemah al-Qur'an dan tafsir), maupun kajian atau penafsiran individu yang dimanfaatkan untuk diri sendiri maupun untuk diajarkan kepada masyarakat. Dosen berinisial SM, misalnya menyatakan bahwa "saya mengakaji dan membahas pesan-kesan dan misi al-Qur'an yang harus diterapkan dalam kehidupan sehari-hari untuk kemudian disampaikan kepada anggota jamaahnya." ${ }^{49}$ Di samping itu, ada dosen yang mengkaji alQur'an yang dituangkan dalam bentuk tulisan, dan diterbitkan di beberapa jurnal seperti Komunika, Maghza, dan al-Manabij. ${ }^{50}$ Juga, ada yang menggunakan kandungan ayat-ayat al-Qur'an yang sudah digubah menjadi lagu untuk dituturkan dalam ceramah keagamaan di masyarakat, karena menurutnya jika masyarakat, khususnya anak-anak muda diperdengarkan ayat al-Qur'an secara langsung, mereka akan "lari. ${ }^{51}$ Selain itu, dengan model interaksi ini mereka dapat memperoleh inspirasi dan wawasan baru, menambah kosa kata baru, menemukan dan menikmati keindahan bahasa al-Qur'an, dan memahami makna al-Qur'an.

Bentuk resepsi intelektual tersebut jika dikaji dengan pendekatan resepsi maka akan tampak dua model pembacaan. Sebagian besar kalangan dosen dalam memahaminya dapat dikategorikan pada dominant reading, hal ini tampak pada sebagian kalangan yang memahami dan menerima pemaknaan al-Qur'an baik melalui

\footnotetext{
49 "Wawancara Dengan SM 23 Mei." (Purwokerto, 2017)

50 "Wawancara Dengan EM 22 Mei." (Purwokerto, 2017)

51 "Wawancara Dengan MT 9 Agustus." (Purwokerto, 2017)
} 
terjemah, ceramah, maupun buku tafsir dengan apa adanya, tanpa ada resistensi. Sebagian dosen yang lain bisa digolongkan pada model negotieted reading, misalnya, ketika memahami al-Qur'an dengan media terjemah, ceramah, diskusi, maupun buku tafsir mereka meresepsinya dengan daya kritis, dan mereka akan menerima jika hal tersebut sesuai dengan pandangannya. Sikap yang ditunjukan oleh SM dan MT 9, misalnya, sangat Nampak bagaimana mereka menegosiasikan teks alQur'an agar selaras dengan kondisi dirinya sendiri maupun konteks masyarakat yang menjadi objek dakwahnya.

\section{Resepsi Magis}

Interaksi dosen IAIN Purwokerto dengan al-Qur'an dalam bentuk resepsi magis cukup beragam. Di antaranya dengan bacaan alQur'an, surah-surah atau ayat-ayat tertentu, dan dengan tulisan dari surah, ayat, dan lafal-lafal tertentu, yang dipercaya memberikan dampak positif maupun 'magis' sesuai dengan yang diyakininya. Secara factual, penulis menemukan bahwa interaksi tersebut dimaknai secara beragam seperti membaca surah al-wäqi'ah yang diyakini bisa memudahkan untuk mendatangkan rizki, ${ }^{52}$ memudahkan urusan, mudah diterima oleh masyarkat, obat psikis, menenangkan, bahkan obat fisik, dan lain sebagainya. ${ }^{53} \mathrm{Hal}$ yang hampir sama juga disampaikan oleh dosen berinisial Mrj, bahwa ayat-ayat al-Qur'an dapat digunakan untuk mendoakan orang yang sakit ketika diminta. ${ }^{54}$ Bentuk magis lainnya, ayat-ayat al-Qur'an digunakan untuk mengobati orang yang kesurupan, bahkan menyelesaikan konflik dalam rumah tangga, konflik antar umat, dan konflik antar golongan. ${ }^{55}$ Selain itu, ayat-ayat al-Qur'an digunakan sebagai obat terutama psikis, dan dapat membuat orang yang mencuri mengakui perbuatannya. ${ }^{56}$

Jika model interaksi dalam bentuk magis di atas ditelaah dengan pendekatan resepsi maka sebagian besar kalangan dosen dalam mengamalkannya dapat dikategorikan pada dominant reading. Hal ini tampak, misalnya pada sebagian kalangan yang membaca al-Qur'an, surah, ayat, dan lafal-lafal tertentu atau menuliskannya karena meyakini akan hikmah yang terkandung di dalamnya, yang pada

\footnotetext{
52 "Wawancara Dengan Sfa 15 August."

53 "Wawancara Dengan Rmt 28 Juli" (Purwokerto, 2017).

54 "Wawancara Dengan Mrj 26 Juli" (Purwokerto, 2017).

55 "Wawancara Dengan NF 24 Mei." (Purwokerto, 2017)

56 "Wawancara Dengan CS 29 Juni."
} 
umumnya diperoleh dari guru spiritualnya. Jadi, mereka hanya menerima apa adanya teks-teks yang diminta oleh gurunya untuk membaca sebagai amaliah keseharian maupun teks-teks yang dijadikan sebagai pegangan untuk mendapatkan keutamaan yang diyakininya bisa mendatangkan keajaiban-keajaiban tertentu.

\section{Kesimpulan}

Dari uraian yang dipaparkan dapat disimpulkan bahwa interaksi dosen IAIN Purwokerto dengan al-Qur'an memiliki empat bentuk resepsi, yaitu: pertama, liturgis dalam bentuk mempelajari dan membaca sesuai dengan urutan mushaf uthmani, membaca surahsurah dan ayat-ayat tertentu, membaca surah-surah dan ayat-ayat tertentu yang dipadukan dengan kalimat-kalimat tayyibah, dan menghafalkannya; kedua, resepsi estetis dalam bentuk oralitas maupun tulisan; ketiga, resepsi intelektual dengan memahami, menerjemahkan, menafsirkan, mereformulasikan menjadi teks-teks baru seperti lagulagu yang kemudian ditransmisikan kepada masyarakat; dan keempat, resepsi magis yang termanifestasikan dalam bentuk bacaan maupun tulisan-tulisan teks ayat al-Qur'an yang diyakini memiliki khasiat dan keajaiban tertentu. Empat bentuk resepsi ini sebagian besar merepresentasikan model dominant reading, di mana para dosen banyak yang melakukan amaliah-amaliah yang berkaitan dengan al-Qur'an tersebut dengan apa adanya, sesuai dengan apa yang dia dapatkan dari para gurunya, dan tidak melakukan upaya-upaya negosiasi. Sedangkan sebagian fenomena yang lain, bisa dilihat bahwa beberapa dosen juga melakukan upaya negotieted reading dengan melakukan formulasiformulasi baru dalam pembacaan teks al-Qur'an ayng disesuaikan dengan konteks dirinya maupun konteks masyarakat yang hendak menjadi medan dakwahnya.

\section{Daftar Pustaka}

Adi, Tri Nogroho. "Mengkaji Khalayak Media Dengan Metode Resepsi." Acta Diurna, Vol. 8, No. 1 (2012).

Ahimsa-Putra, Heddy Shri. "The Living al-Qur'an: Beberapa

Perspektif Antropologi." Walisongo: Jurnal Penelitian Sosial Keagamaan, Vol. 20, No. 1 (2012).

Bukhāri (al), Muhammad b. Ismā̄ill. Al-Jämi al-Saḥịh al-Bukhārì. Beirut: Dār Ṭawq al-Najāt, 1422.

Qāsimi (al), Muḥammad Jamāl al-Dīn b. Muḥammad Sa đāid b. Qāsim al 
Hallaq. Maw'izat al-Mu'minìn min Ibyà' 'Ulum al-Dīn. Beirut: Dār al-Kutub al-'Ilmiyah, t.th.

Anwar, Saifuddin. Metode Penelitian. Yogyakarta: Pustaka Pelajar, 1998. Atabik, Ahmad. "The Living Qur'an: Potret Budaya Tahfiz al-Qur'an di Nusantara." Jurnal Penelitian, Vol. 8, No. 1 (2014).

Hakiemah, Ainun dan Jazilus Sakhok. "Khataman al-Qur'an di Pesantren Sunan Pandanaran Yogyakarta: Kajian Living Hadis." Mutawatir: Jurnal Keilmuan Tafsir Hadith, Vol. 9, No. 1 (2019).

Isnawati. "Studi Living Qur'an Terhadap Amalan Ibu Hamil." Studia Insania, Vol. 3, No. 2 (2015).

Kriyantono. Teknik Praktis Media Komunikasi. Jakarta: Kencana Prenada Media Grup, 2007.

Lexy, Moleong J. Metodologi Penelitian Qualitatif. Bandung: PT Remaja Rosdakarya, 1996.

Muhtador, Moh. "Pemaknaan Ayat Al-Quran Dalam Mujahadah: Studi Living Qur'an Di PP Al-Munawwir Krapyak Komplek AlKandiyas Moh." Jurnal Penelitian, Vol. 8, No. 1 (2014).

Murley, David. Family Televition, Cultural Power and Domintic Leisure. London: A Comedia Book, 1986.

Prodjodikoro, Suyatno. "Dimensi Sosial dan Spiritual Semaan AlQur'an 'MANTAP' di Yogyakarta." Al-Jami'ab: Joumal of Islamic Studies, Vol. 39, No. 1 (2001).

Sudarmoko, Imam. "The Living Qur'an; Studi Kasus Tradisi Sema'an al-Qur'an Sabtu Legi Di Masyarakat Sooko Ponorogo.” Tesis, Universitas Islam Negeri Maulana Malik Ibrahim Malang, Malang, 2016.

Syamsuddin, Sahiron. "Metodologi Penelitian Living Qur'an Dan Hadis," dalam Metodologi Penelitian Living Qur'an Dan Hadis. Diedit oleh Sahiron Syamsuddin. Yogyakarta: Teras, 2007.

Turmudhì (al), Abū 'Isā Muhammad b. 'Tsā. Sunan Al-Turmudhī.

Beirut: Dār al-Gharb al-Islami, 1988.

"Wawancara Dengan CS 29 Juni." Purwokerto, 2017.

"Wawancara Dengan EM 22 Mei." Purwokerto, 2017.

"Wawancara Dengan EW and BU 25 Juli." Purwokerto, 2017.

"Wawancara Dengan HK 13 Juni." Purwokerto, 2017.

"Wawancara Dengan HM 7 Juni." Purwokerto, 2017.

"Wawancara Dengan Htn 25 Mei." Purwokerto, 2017.

"Wawancara Dengan MH 24 Mei." Purwokerto, 2017.

"Wawancara Dengan MR 15 Agustus." Purwokerto, 2017. 
“Wawancara Dengan Mrj 26 Juli.” Purwokerto, 2017.

"Wawancara Dengan MT 9 Agustus." Purwokerto, 2017.

"Wawancara Dengan Mtj 12 Juni." Purwokerto, 2017.

"Wawancara Dengan Mw 25 Mei." Purwokerto, 2017.

"Wawancara Dengan NF 24 Mei." Purwokerto, 2017.

"Wawancara Dengan NM 15 Mei." Purwokerto, 2017.

"Wawancara Dengan Rmt 28 Juli." Purwokerto, 2017.

"Wawancara Dengan Rq 15 Agustus." Purwokerto, 2017.

"Wawancara Dengan SB 7 Juni." Purwokerto, 2017.

"Wawancara Dengan Sfa 15 August." Purwokerto, 2017.

"Wawancara Dengan SI 24 Mei." Purwokerto, 2017.

"Wawancara Dengan SM 23 Mei." Purwokerto, 2017.

"Wawancara Dengan Spn 20 Mei." Purwokerto, 2017.

"Wawancara Dengan SS 27 Juni." Purwokerto, 2017.

"Wawancara Dengan WT 2 Mei." Purwokerto, 2017.

"Wawancara Dengan YP 23 Mei." Purwokerto, 2017.

“Wawancara Dengan YSS, CW, YE 5 Juni.” Purwokerto, 2017. 